\title{
Bioassay techniques for determination of the dose of Atrazine and Pendimethalin as pre and post-emergence for Maize (Zea mays) in Terai region of West Bengal
}

\author{
Chhetri B, Ahmed. S, Mahata D and *S.K. Mahato* \\ Department of Agronomy, Department of pomology and post Harvest Technology Uttar Banga Krishi \\ Viswavidyalaya, Pundibari, CoochBehar-736165
}

Abstract: Field experiment was carried out during the rabi season of 2013 in the research farm of Uttar Banga Krishi Viswavidyalaya located at Pundibari, Coochbehar, (W.B). The soil of the experimental site was sandy loam in character. Ten treatments under each herbicide were setup with plot size of $2 X 3 M$ in maize verity (JKMH-1001). The dose of different herbicides $(\mathrm{kg} / \mathrm{ha})$ for the both treatment [Post-emergence application (PPSA) and Pre-emergence application (PE)].

\section{Introduction}

In weed research, bioassay is used to measure the biological response of living plant to herbicide and to quantify its concentration in a substrate. Bioassay is usually conducted with sensitive plant species also referred to as indicator or test species. Bioassay is being used widely as a useful tool to regulate herbicide doses in a particular crop. This technique also leads to identify the herbicide that is safe for a crop in terms of phytotoxicity and growth reduction by relating the different herbicidal doses with percent reduction in fresh weight as individual plants. (Tag et. Al.1981). The bioassay experiment has been conducted at the research farm of Uttar Banga Krishi Viswavidyalaya in maize with the following objectives.

- To find out the dose of Atrazine and Pendimethalin in Maize and their time of application.

- To measure selectivity index (SI) of the herbicides.

- To study the comparative performance of the herbicides based on SI, time of application and dose.

\section{Methodology}

Field experiment was carried out during the rabi season of 2013 in the research farm of Uttar Banga Krishi Viswavidyalaya located at Pundibari, Coochbehar, (W.B). The soil of the experimental site was sandy loam in character. Ten treatments under each herbicide were setup with plot size of $2 \mathrm{X} 3 \mathrm{M}$ in maize verity (JKMH-1001). The dose of different herbicides ( $\mathrm{kg} / \mathrm{ha}$ ) for the both treatment [Post-emergence application (PPSA) and Pre- emergence application(PE)].

Table: 1 Effect of different doses of herbicides as pre and post-emergence $(\mathrm{kg} / \mathrm{h})$

\begin{tabular}{|c|c|c|c|c|}
\hline \multirow[t]{2}{*}{ Herbicide doses } & \multirow{2}{*}{$\begin{array}{c}\text { Pendimethalin } \\
\text { Pre-emergence } \\
\text { application }\end{array}$} & \multirow{2}{*}{$\begin{array}{c}\text { Atrazine } \\
\begin{array}{c}\text { Pre-emergence } \\
\text { application }\end{array}\end{array}$} & \multicolumn{2}{|c|}{ Atrazine } \\
\hline & & & $\begin{array}{c}\text { Post-emergence } \\
\text { application(20DAS) }\end{array}$ & $\begin{array}{c}\text { Post-emergence } \\
\text { application(40DAS) }\end{array}$ \\
\hline 1 & 0.00 & 0.00 & 0.00 & 0.00 \\
\hline 2 & 0.10 & 0.10 & 0.10 & 0.10 \\
\hline 3 & 0.20 & 0.20 & 0.20 & 0.20 \\
\hline 4 & 0.30 & 0.30 & 0.30 & 0.30 \\
\hline 5 & 0.40 & 0.40 & 0.40 & 0.40 \\
\hline 6 & 0.60 & 0.60 & 0.60 & 0.60 \\
\hline 7 & 0.80 & 0.80 & 0.80 & 0.80 \\
\hline 8 & 1.00 & 1.00 & 1.00 & 1.00 \\
\hline 9 & 1.50 & 1.50 & 1.50 & 1.50 \\
\hline 10 & 2.00 & 2.00 & 2.00 & 2.00 \\
\hline
\end{tabular}

The per cent growth inhibition values obtained at different herbicidal doses both in case of Maize and weed were transformed to probit values and regressed against log values of doses. The linear regression equation was computed by using excel programmed $\mathrm{Y}=\mathrm{bx}+\mathrm{a}$, where $\mathrm{Y}$ indicates probit value of per cent dry weight reduction, $\mathrm{b}$ is regression coefficient, $\mathrm{x}$ is $\log$ dose of herbicide and a is intercept of $\mathrm{Y}$. Selectivity index (S.I.) value was calculated by using the following formula:

S.I.=Maximum dose tolerated by crop(Maize)/Minimum dose required to control weed

Maximum dose of herbicide tolerated by maize was equal to dose that caused $15 \%$ growth reduction of Maize $\left(\mathrm{GR}_{15}\right)$ at initial stages and minimum dose required to control the weeds was equal to the dose that resulted in $80 \%$ growth reduction in weed $\left(\mathrm{GR}_{80}\right)$ or $80 \%$ weed control efficiency of herbicide. Selectivity index 
value greater than 1 is always desirable to get selective control over weeds without any lethal effect on crop plant. The proportional increase of plant response in terms of growth reduction to herbicidal doses led to identify the level at which the plant produce $50 \%$ response which is known as $\mathrm{GR}_{50}$ (dose of herbicide that led to $50 \%$ growth reduction).

The following weed flora were recorded during the experimentation

Cynodon dactylon, Cyperus rotundus,

Cyperus $\underline{\text { iria, }}$ Oxalis spp

\section{Result}

- ATRAZINE

Pre-emergence Probit value of crop

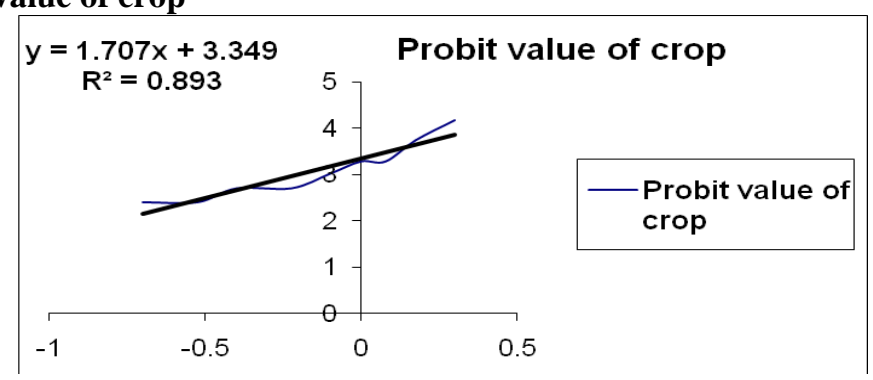

- Calculation of $\mathbf{G R}_{15}$

$\mathrm{Y}=$ Probit Value of $15 \%$ growth reduction of Maize i.e. 3.50

$3.50=1.7079 \mathrm{x}+3.349$

Then $\mathrm{x}=0.0883$

Anti $\log$ of $0.0883-=1.2$, then $\mathrm{GR}_{20}=1.2 \mathrm{~kg} / \mathrm{ha}$. dose of Atrazine

- Calculation of $\mathbf{G R}_{\mathbf{5 0}}$

Y=Probit Value of $50 \%$ growth reduction of maize i.e. 5.22

$5.22=1.7079 \mathrm{x}+3.349$

Then $\mathrm{x}=1.0954$

Anti $\log$ of $1.0954=12.5$, then $\mathrm{GR}_{50}=12.5 \mathrm{~kg} / \mathrm{ha}$ dose of Atrazine.

Probit value of weed

Calculation of $\mathbf{G R}_{\mathbf{8 0}}$

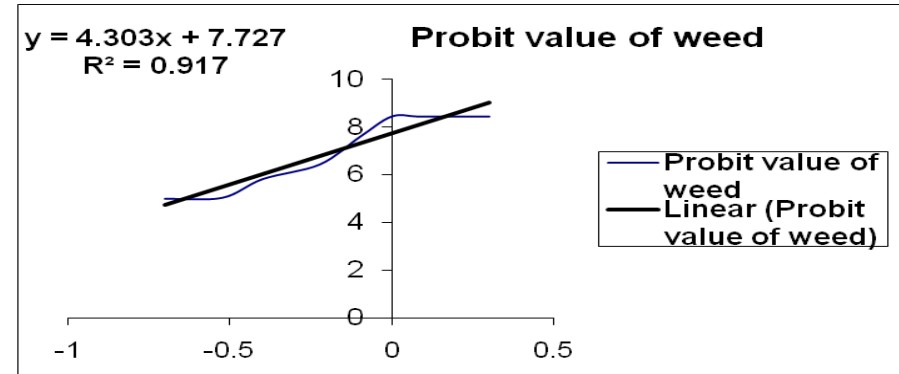

$\mathrm{Y}=$ Probit Value of $80 \%$ growth reduction of weed i.e 6.88

$6.88=4.3031 \mathrm{x}+7.727$

Then $\mathrm{x}=-0.1969$

Anti $\log$ of $0.1969=0.6$, then $\mathrm{GR}_{80}=0.6 \mathrm{~kg} / \mathrm{ha}$. dose of Atrazine

\section{PENDIMETHALIN}

Pre-emergence Probit value of crop 


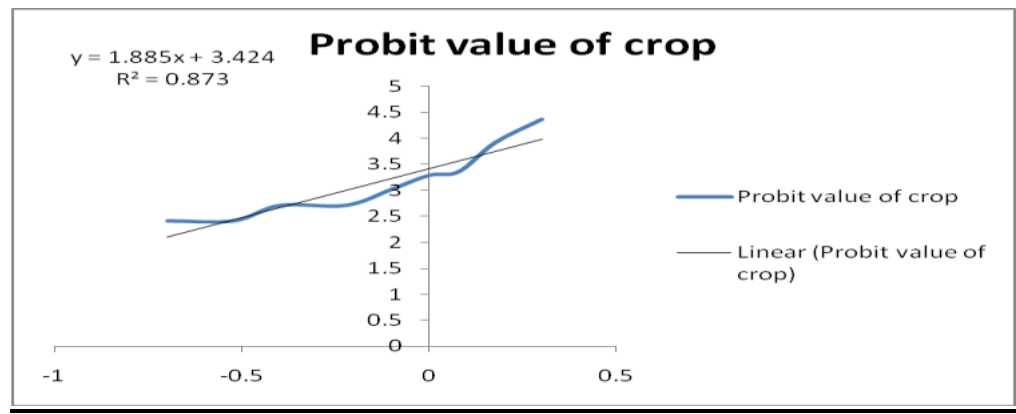

- Calculation of $\mathbf{G R}_{15}$

$\mathrm{Y}=$ Probit Value of $15 \%$ growth reduction of Maize i.e 3.50

$3.50=1.885 \mathrm{x}+3.424$

Then $\mathrm{x}=.053$

Anti $\log$ of $.053=1.1$, then $\mathrm{GR}_{20}=0.1 .1 \mathrm{~kg} / \mathrm{ha}$. dose of Pendimethalin

- Calculation of $\mathbf{G R}_{50}$

$\mathrm{Y}=$ Probit Value of $50 \%$ growth reduction of maize i.e. 5.22

$5.22=1.1 .885 \mathrm{x}+3.424$

Then $\mathrm{x}=0.9527$

Anti $\log$ of $0.9527=8.9$, then $\mathrm{GR}_{50}=8.9 \mathrm{~kg} / \mathrm{ha}$ dose of Pendimethalin.

Probit value of weed

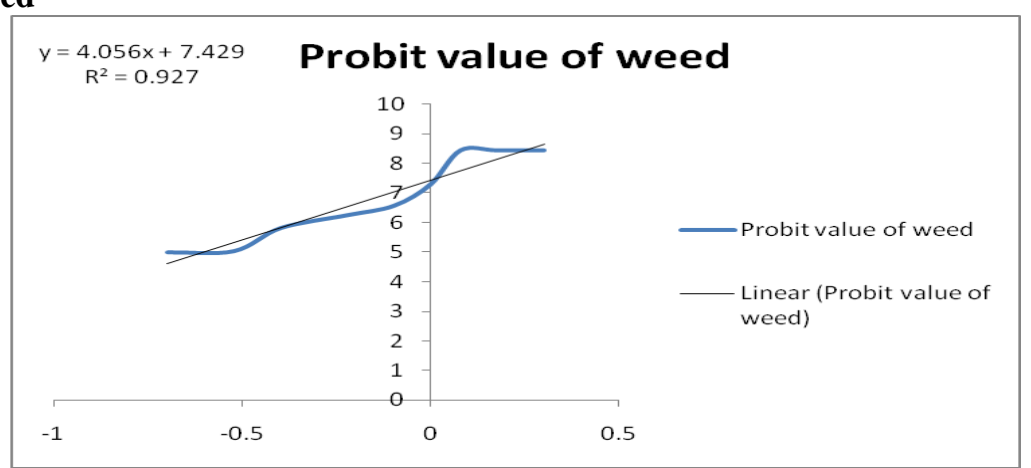

- Calculation of $\mathbf{G R}_{80}$

Y=Probit Value of $80 \%$ growth reduction of weed i.e 6.88

$6.88=4.056 \mathrm{x}+7.429$

Then $\mathrm{x}=-0.1$

Anti $\log$ of $-0.1=0.8$, then $\mathrm{GR}_{80}=0.8 \mathrm{~kg} / \mathrm{ha}$. dose of Pendimethalin.

ATRAZINE

Post-emergence (20 DAS)

Probit value of crop

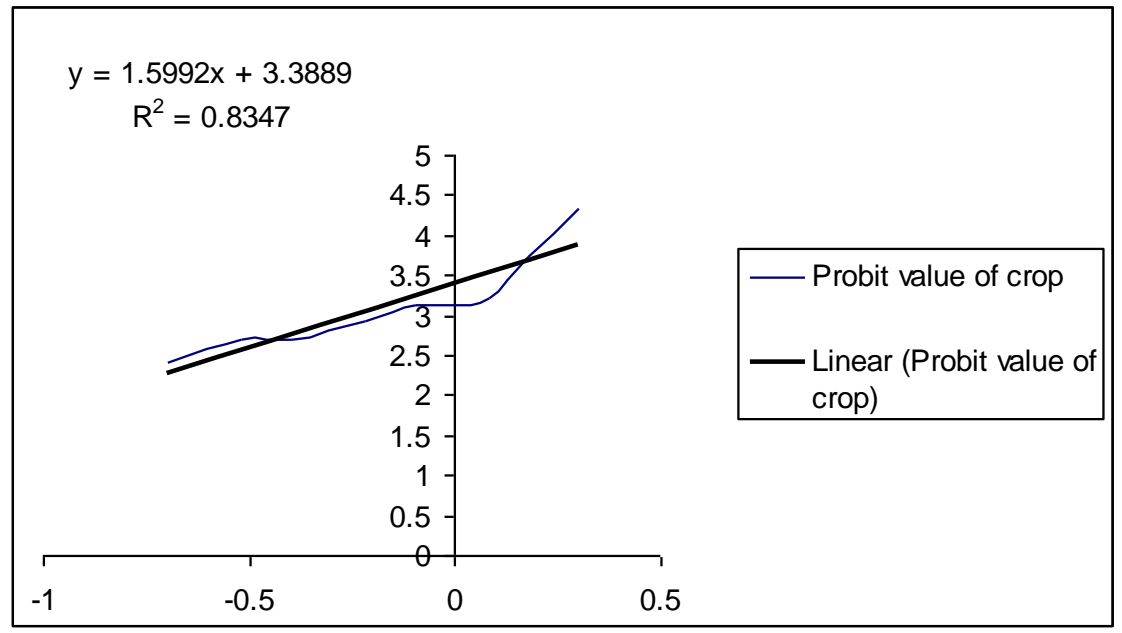


- Calculation of $\mathbf{G R}_{15}$

$\mathrm{Y}=$ Probit Value of $15 \%$ growth reduction of Maize i.e. 3.50

$3.50=1.5992 x+3.3889$

Then $\mathrm{x}=0.1$

Anti $\log$ of $0.1=1.3$, then $\mathrm{GR}_{15}=1.3 \mathrm{~kg} / \mathrm{ha}$. dose of Atrazine

- Calculation of $\mathbf{G R}_{50}$

$\mathrm{Y}=$ Probit Value of $50 \%$ growth reduction of maize i.e. 5.22

$5.22=1.5992 x+3.3889$

Then $\mathrm{x}=1.1$

Anti $\log$ of $1.1=12.6$, then $\mathrm{GR}_{50}=12.6 \mathrm{~kg} / \mathrm{ha}$ dose of Atrazine.

Probit value of weed

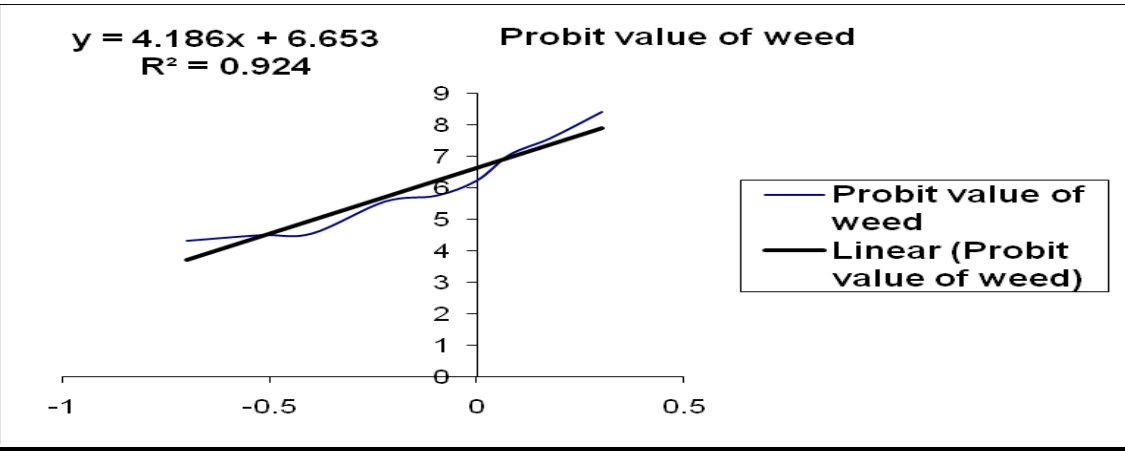

Y=Probit Value of $80 \%$ growth reduction of weed i.e 6.88

$6.88=4.186 \mathrm{x}+6.653$

Then $\mathrm{x}=.054$

Anti $\log$ of $0.54=1.1$, then $\mathrm{GR}_{80}=1.1 \mathrm{~kg} / \mathrm{ha}$. dose of Atrazine

ATRAZINE

Post-emergence (40DAS) Probit value of crop

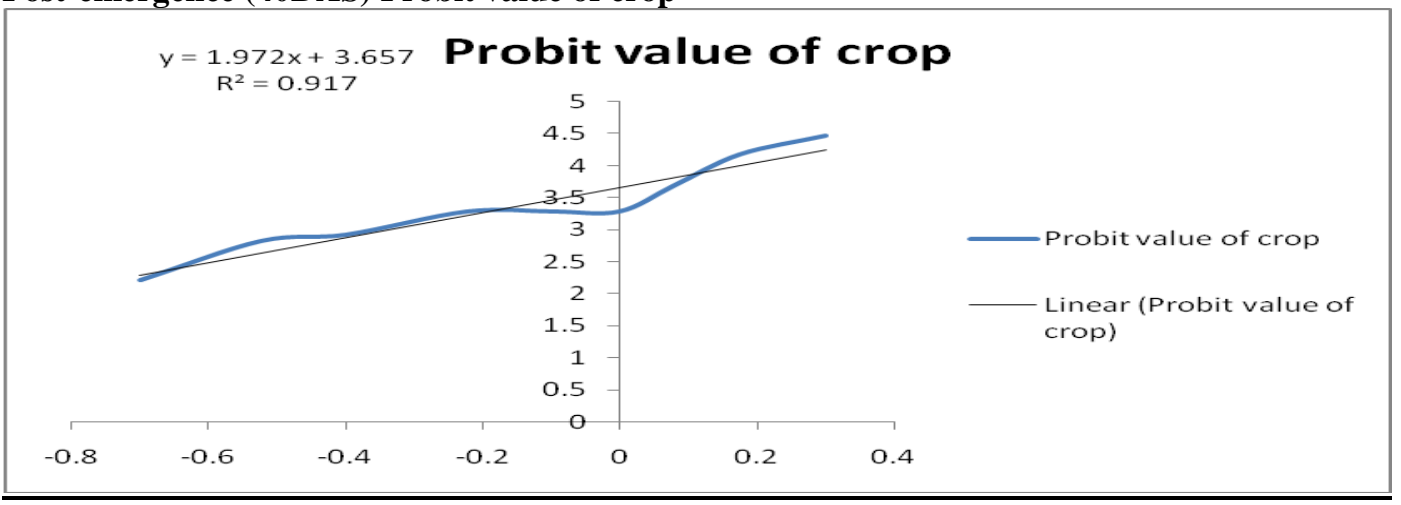

- Calculation of $\mathbf{G R}_{15}$

Y=Probit Value of 15\% growth reduction of Maize i.e 3.50

$3.50=1.972 \mathrm{x}+3.657$

Then $\mathrm{x}=-0.1$

Anti $\log$ of $-0.1=0.8$, then $\mathrm{GR}_{20}=0.8 \mathrm{~kg} / \mathrm{ha}$. dose of Atrazine

- Calculation of $\mathbf{G R}_{50}$

$\mathrm{Y}=$ Probit Value of $50 \%$ growth reduction of maize i.e. 5.22

$5.22=1.972 \mathrm{x}+3.657$

Then $\mathrm{x}=0.8$

Anti $\log$ of $0.8=6.3$, then $\mathrm{GR}_{50}=6.3 \mathrm{~kg} / \mathrm{ha}$ dose of Atrazine.

Probit value of weed 


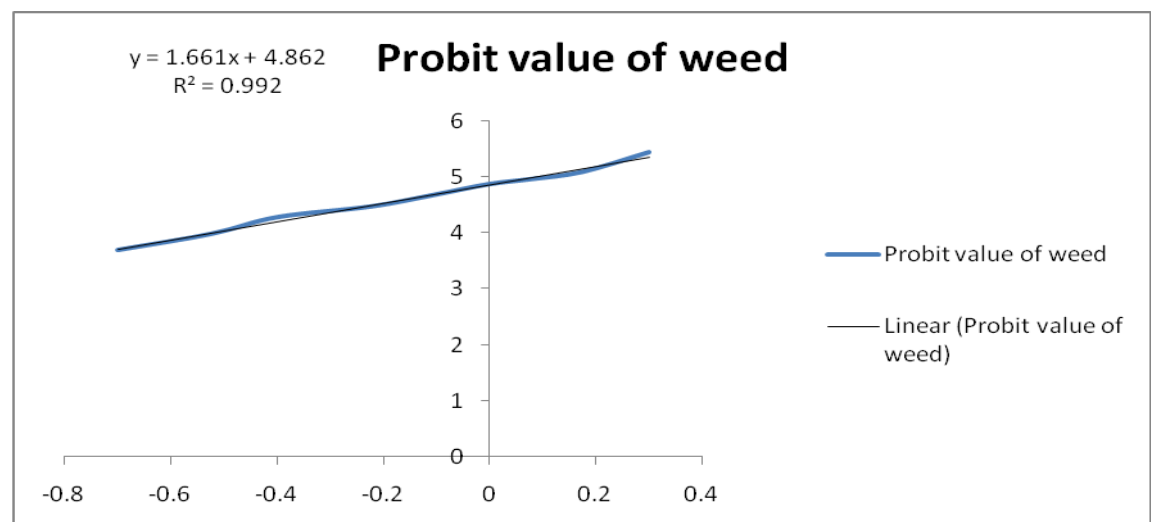

- Calculation of $\mathbf{G R}_{80}$

Y=Probit Value of $80 \%$ growth reduction of weed i.e 6.88

$6.88=1.661 \mathrm{x}+4.862$

Then $\mathrm{x}=1.2$

Anti $\log$ of $1.2=15.8$, then $\mathrm{GR}_{80}=15.8 \mathrm{~kg} / \mathrm{ha}$. dose of Atrazine

Table 2: $G R_{15}, G^{50}$ of Maize, $G_{R_{80}}$ of weed and SI value of the herbicides

\begin{tabular}{|c|c|c|c|c|c|c|c|c|}
\hline \multirow[t]{2}{*}{ Herbicide } & \multirow{2}{*}{$\begin{array}{c}\text { Maximum } \\
\text { dose(kg/ha) } \\
\text { tolerated } \\
\text { by crop } \\
\left(\mathrm{GR}_{1}\right)\end{array}$} & \multirow{2}{*}{$\begin{array}{c}\text { Minimum } \\
\text { dose }(\mathrm{kg} / \mathrm{ha}) \\
\text { required to } \\
\text { control } \\
\text { weed }\left(\mathrm{GR}_{80}\right)\end{array}$} & \multirow[t]{2}{*}{$\begin{array}{l}\text { Selectivity } \\
\text { Index(SI) }\end{array}$} & \multirow{2}{*}{$\begin{array}{c}\text { GR }_{50} \\
\text { value(kg/ha) } \\
\text { of Maize }\end{array}$} & \multicolumn{2}{|c|}{$\begin{array}{c}\text { Linear regression } \\
\text { equation }\end{array}$} & \multicolumn{2}{|c|}{$\mathbf{R}^{2}$ value } \\
\hline & & & & & crop & Weed & crop & weed \\
\hline $\begin{array}{c}\text { Atrazine } \\
\text { Pre-emergence }\end{array}$ & 1.2 & 0.6 & 2.00 & 12.5 & $\begin{array}{c}\mathrm{Y}=1.707 \mathrm{x} \\
+3.349\end{array}$ & $\begin{array}{c}\mathrm{Y}=4.303 \mathrm{x} \\
+7.727\end{array}$ & 0.893 & 0.917 \\
\hline$\frac{\text { Pendimethalin }}{\text { Pre-emergence }}$ & 1.1 & 0.8 & 1.375 & 8.9 & $\begin{array}{c}\mathrm{Y}=1.885 \mathrm{x} \\
+3.424\end{array}$ & $\begin{array}{c}\mathrm{Y}=4.056 \mathrm{x} \\
+7.429\end{array}$ & 0.873 & 0.927 \\
\hline $\begin{array}{c}\text { Atrazine } \\
\text { post- } \\
\text { emergence(20DAS) }\end{array}$ & 1.3 & 1.1 & 1.1818 & 12.6 & $\begin{array}{c}\mathrm{Y}= \\
1.5992 \mathrm{x} \\
+3.3889\end{array}$ & $\begin{array}{c}\mathrm{Y}=4.186 \mathrm{x} \\
+6.653\end{array}$ & 0.8347 & 0.924 \\
\hline $\begin{array}{c}\text { Atrazine } \\
\text { post- } \\
\text { emergence(40DAS) }\end{array}$ & 0.8 & 15.8 & 0.1 & 6.3 & $\begin{array}{l}\mathrm{Y}= \\
1.9724 \mathrm{x} \\
+3.6574\end{array}$ & $\begin{array}{c}\mathrm{Y}=1.6613 \mathrm{x} \\
+4.8629\end{array}$ & 0.9724 & 0.9925 \\
\hline
\end{tabular}

\section{Conclusion}

Maximum up to $1.2 \mathrm{~kg} / \mathrm{ha}$ of Atrazine can selectively be used in Maize under pre-emergence application . However, minimum dose required to control the weed is $0.6 \mathrm{~kg} / \mathrm{ha}$ with the SI value of 2.00 . Whereas in pre -emergence treatment of Pendimethalin ,maximum and minimum doses are $1.1 \mathrm{~kg} / \mathrm{ha}$ and 0.8 $\mathrm{kg} / \mathrm{ha}$, respectively, with the SI value of 1.375 . Low SI value in pre- emergence treatment of Pendimethalin treatment makes the treatment less selective than that of pre -emergence treatment in atrazine. Therefore, the dose $0.6 \mathrm{~kg} / \mathrm{ha}$ Atrazine can be applied in Maize safely as pre-emergence for controlling weeds.

Maximum up to $1.3 \mathrm{~kg} / \mathrm{ha}$ Atrazine can selectively be used for maize under post-emergence application (20DAS).However, minimum dose required to control the weed is $1.1 \mathrm{~kg} / \mathrm{ha}$ with the SI value of 1.1818. Whereas in post-emergence treatment (40DAS), maximum and minimum doses are $0.8 \mathrm{~kg} / \mathrm{ha}$ and 15.8 $\mathrm{kg} / \mathrm{ha}$ respectively, with the SI value of 0.1. Low SI value in post-emergence treatment (40DAS), makes the treatment less selective than that of post-emergence treatment (20DAS). Therefore, the dose of $1.1 \mathrm{~kg} / \mathrm{ha}$ can be applied in Maize safely as post-emergence application treatment controlling weeds.

\section{References}

[1]. Tag, E,I,. Din, A., Ibrahim, A.M., Khalfia, M.A.S., Komeil, A.A. and Bassoumy, M. 1981. Evaluation of some herbicides in soyabean fields in A.R.Egypt, paper presented at $33^{\text {rd }}$ International symposium on crop protection. Mededelingen Van de Faculteit. Ladhouwweteschappen, Rijksuniversiteit. Gent, 46, (1): 173-181

[2]. Raj M.F. et al 1999: pendimethalin, fluchloralin and oxidiazon residue in/on onion. Pesticide Research Journal 11 (1): 68-70 